\title{
THE PROBLEM OF "HIDDEN" ICE IN GLACIER MAPPING
}

\author{
by
}

W.B. Whalley and H. Elizabeth Martin

(Department of Geography, The Queen's University, Belfast BT7 1NN, UK)

and

Anne F. Gellatly

(Department of Geography, Sheffield University, Sheffield S10 2TN, UK)

\begin{abstract}
Ice can become "hidden", i.e. buried, by the superimposition of rock debris on a glacier or where rock debris may incorporate interstitial ice. Because it is obscured, problems result from a lack of understanding of the extent and continued activity of such ice. Landforms may be associated with this phenomenon and can be used as indirect evidence of its existence. A rock glacier can contain glacially-derived, buried ice as well as interstitial ice. We show, with examples, how such rock glaciers can be identified and provide information on the extent and possible volume of hidden ice in marginally glacierized and permafrost areas. In most cases, recognition of topography is sufficient, although time-separated aerial photographs may be necessary to locate the extent of ice. These are generally preferable to, and more cost effective than, most detailed on-site determinations of ice extent. It is possible to incorporate and extend knowledge of hidden ice in glacier mapping and inventory projects.
\end{abstract}

\section{INTRODUCTION}

A knowledge of the extent and occurrence of ice hidden by rock debris can be of use, for several purposes, the most obvious of which are engineering projects, ice inventories, and investigations into local changes in glacier mass balance.

The term "hidden ice" refers to ice of glacial origin, obscured by accumulating supraglacial rock debris, or to ice incorporated within a debris mass. Rock glaciers constitute one landform which may contain substantial amounts of such hidden ice.

Rock glaciers have been a subject of some academic dispute as to their origins and significance. This confusion has resulted from a lack of understanding of the extent, nature, and activity of the hidden ice. Some accept that rock glaciers are, in essence, debris-covered glaciers and hence have, whilst active, a glacier ice core (Potter 1972, Corte 1976, Whalley 1983). Such a core has been suggested by observations of exposed sections and through the association of glacial topography and environment (Outcalt and Benedict 1965). Based on results from geophysical soundings and drillings, other authors conclude that rock glaciers have a permafrost origin with ice content of a predominantly interstitial segregational nature (Barsch 1977, Haeberli 1985), whilst others, again, (White 1976) believe that both types occur. In this paper, since our concern is with the recognition of hidden ice rather than strict glacio-geomorphic interpretation, we concentrate on supposedly glacially-derived forms, although it is accepted that non-glacially-derived rock glaciers can contain substantial quantities of hidden ice. Both types need to be accommodated in glacier inventories. In Argentina, for example, rock glaciers supply all the stream water in some valleys (Corte 1976).

\section{IDENTIFICATION, INTERPRETATION AND ORIGIN OF HIDDEN ICE}

An inherent difficulty in providing an explanatory classification of landforms derived from hidden ice is the continuum from clear, specific features - easily recognised and cited in the literature - to indistinct forms which are usually ignored, due to problems of identification, classification, and origin determination.

The visual recognition and interpretation of features are, as always, subject to the judgement of the individual researcher and this, too, can present problems, for example, the arguments of Barsch (1971) and Østrem (1971) concerning identification of rock glaciers and ice-cored moraines and, later, that of push moraines (Haeberli 1979). Although this may appear to be academic, it reveals a manifest difficulty in really knowing what is hidden. As well as problems with the identification of hidden ice, difficulties can arise in the interpretation of the origin of the features. Figure 1 illustrates the complexity of the various forms in which ice may be buried (see e.g. Eyles 1979). Four factors need to be considered in any location: 1. the activity of any ice supply, 2. the rate of supply of rock debris to cover any ice, 3 . water or snow melt to supply ground ice in rock debris, and 4. the (mean annual) air temperature. These are not completely independent, because rock glacier acitivity will depend upon the quantity of ice and, hence, upon the general climatic environment;

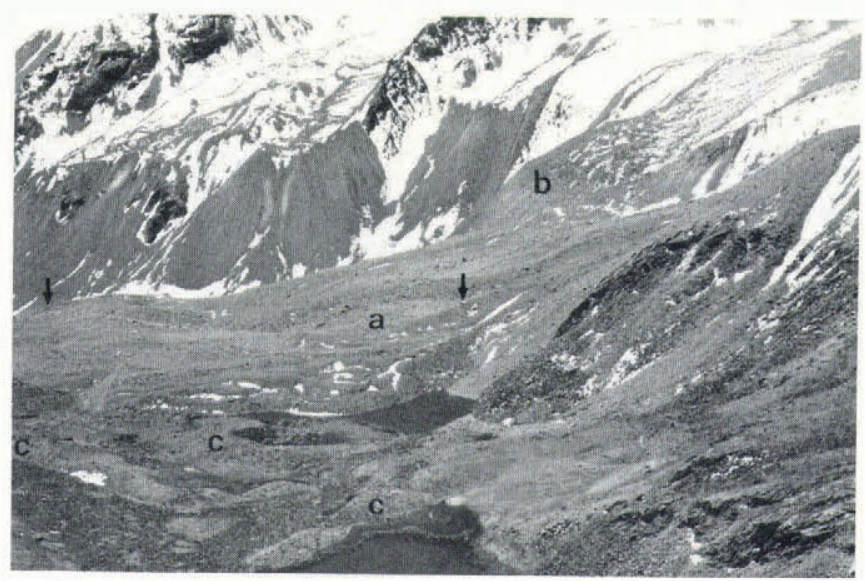

Fig.1. Shows a rock glacier, with the main topographic features mentioned in the text, which we believe to be a debris-covered, glacier snout (a), which has the form of a rock glacier in the visible, lower portion, but has bare ice higher up the valley. Another rock glacier snout is visible at (b). Small moraines (known to have no ice cores) are visible at (c). Length between arrows approximately $500 \mathrm{~m}$; Hindu Kush Mountains, Afghanistan. 
this is also related to the amount of melting ice below any debris cover (Whalley 1983) and general permafrost conditions (Haeberli 1985). Hence, the exact location and quantity of hidden ice may be influenced in several ways.

All these problems make it especially difficult to provide hard and fast rules for the identification of hidden ice, although considerable aid is given by the recognition of rock glaciers as a storage medium. To illustrate how these affect the accuracy and application to glacier mapping, we consider the example of hidden ice in the form of rock glaciers.

\section{ROCK GLACIER IDENTIFICATION}

Glacier inventories have sometimes included identification of rock glaciers as part of the survey (Corte 1980) and, in the UNESCO guide for a world inventory of perennial snow and ice masses, Müller (1970) proposed that rock glaciers should be included. Whatever the origin of the ice, the fact that considerable quantities may be involved suggests that this is reasonable. The following morphological criteria can aid in the identification of rock glaciers, using terrestrial surveys or aerial photographs;

1. They are found in mountainous regions which have, or have had, glacial/periglacial conditions.

2. They have the outward appearance of being composed of rock debris.

3. They show the extent of this rock debris as distinct limits, both marginally and terminally (but less distinctly at their heads).

4. They have a debris source area (or areas), i.e. a head, and, in addition, a distinct snout which marks their maximum extent down-slope.

5. They have, in many cases, flow-like features on their surface. The rock glacier is supposed to flow (or have flowed, in the case of relict features), as a result of ice contained in some manner within the rock debris.

Further discussion on the possible morphologies can be found in Washburn (1979) and White (1981). With aerial photography, the form is of ten topographically distinct, but, in false colour, any older rock glaciers of ten appear to merge with surrounding vegetation and can thus be easily missed, compared with vegetation-free features. Even rock glaciers with vegetated surfaces may still contain ice.

Most of the features listed are illustrated in Figure 2, though it should be noted that the flow structures in this example are not very distinct. Morphological definitions may be problematic when the feature studied does not possess all the "classic" attributes. Identification is only the beginning of the study; we now have to examine more closely the hidden-ice component of the rock glacier and here a number of questions may be asked. 1. Where is the ice located? 2. How much ice are we dealing with? and 3. What state of activity is this ice in? These questions may of ten be answered through analysis of changes in the

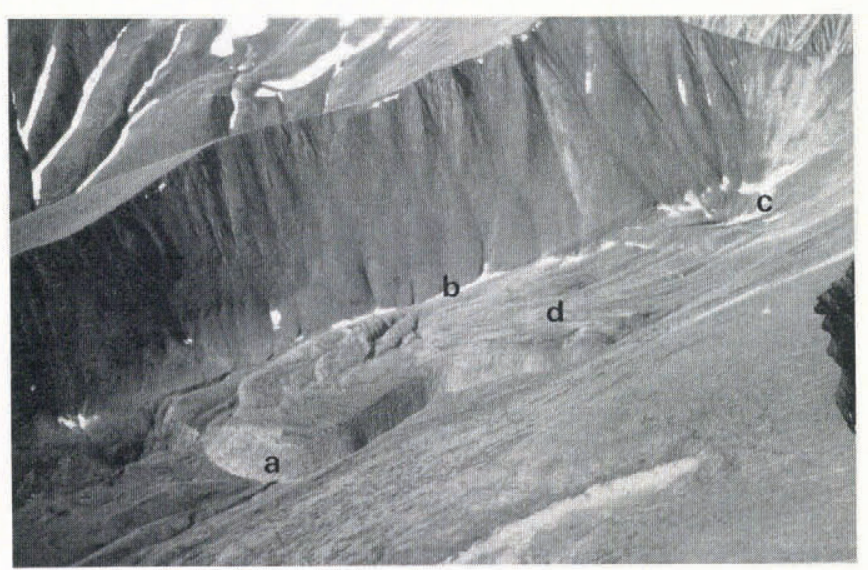

Fig.2. Small rock glacier in the Wrangell Mountains, Alaska, showing typical features: a) steep snout, b) distinct margins, c) head with snow patch rather than glacier, d) flow-ridge structures. The lower portion of the tongue is partially vegetated.

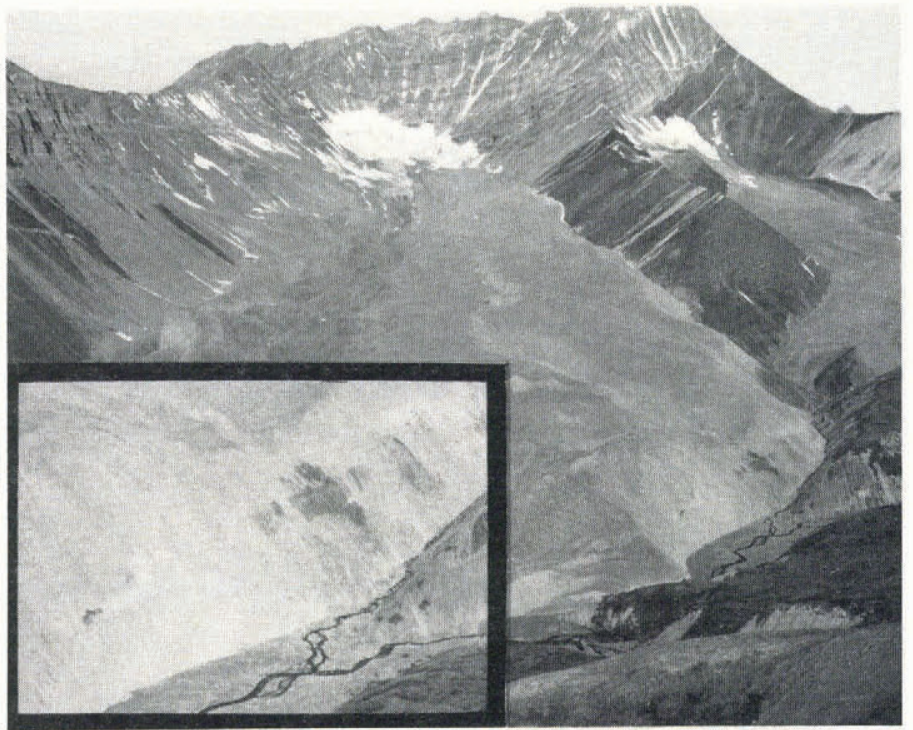

Fig.3. Andrus Peak rock glacier (Wrangell Mountains), about $2 \mathrm{~km}$ long. There is no vegetation on this rock glacier and ice can be seen melting out at the snout (inset). Collapse features, indicative of ice melt, can be found on the surface.

surface characteristics of the rock glacier, but aerial photographs with considerable time-separation may be required for this (e.g. Barsch and Hell 1976, Messerli and Zurbuchen 1968).

Figure 3 shows how a single observation can indicate the presence of hidden ice. Melting ice near the snout shows a darkened line of damp debris; this could be interpreted as an ice core, very near the terminus. Some rock glaciers have, at the snout, slope angles well below the resting angle of the debris ("inactive" rock glaciers) and may, indeed, be heavily vegetated. In such cases the down-valley extent of ice is completely masked, but one would suspect that the ice volume here is small. However, the appearance of the rock-glacier snout may belie the actual state of ice activity (Whalley 1983). Generally speaking, active snouts have a sharp angle between the top and front surfaces, wheras inactive snouts are characteristically rounded.

A detailed examination of the surface features of a rock glacier may also give a general indication of the position, activity, and quantity of hidden ice. A range of features, such as melting and collapses around crevasses, can be identified, which indicate ice limits and, to some extent, debris thickness. Glacier ice may also be exposed around pools developed on or next to the rock glacier (e.g. Whalley 1979). A pitted surface (thermokarst depressions) is generally a good indicator of the existence of glacier ice below a debris cover (Fig.1, Fig.2), although large ice lenses of interstitial ice might also produce such features. However, such an approach can of ten only result in a general appreciation of the location, extent, and volume of hidden ice. For detailed knowledge of the presence of ice, techniques, such as (in increasing time and cost), the "BTS method" of snow temperature determination, contactless (inductive) resistivity, traditional array techniques of resistivity and seismic refraction, radio echo-sounding, and direct drilling, may need to be employed. Most of these methods have been employed in the investigation of rock glaciers and are summarized in Haeberli (1985).

\section{CONCLUSIONS}

Hidden ice can make up a substantial proportion of ice in some areas (Espizua 1983) and rock glaciers are of ten the chief landforms involved. With information on the extent and occurrence of hidden ice, studies of terrain analysis can be enhanced. It may thus be possible to re-evaluate the environmental (and economic) significance of hidden ice, which could benefit projects in the marginally glaciated areas, where rock glaciers tend to occur. 


\section{REFERENCES}

Barsch D 1971 Rock glaciers and ice-cored moraines. Geografiska Annaler 53A(3-4): 203-206

Barsch D 1977 Nature and importance of mass-wasting by rock glaciers in Alpine permafrost environments. Earth Surface Processes 2(2-3): 231-245

Barsch D, Hell G 1976 Photogrammetrische Bewegungsmessungen am Blockgletscher Murtèl 1 , Oberengadin, Schweizer Alpen. Zeitschrift für Gletscherkunde und Glazialgeologie 11(2), 1975: 111-142

Corte A E 1976 Rock glaciers. Biuletyn Peryglacjalny 26: 175-197

Corte A E 1980 Glaciers and glaciolithic systems of the central Andes. International Association of Hydrological Sciences Publication 126 (Workshop at Riederalp 1978World Glacier Inventory): 11-24

Espizúa L E 1983 Glacier and moraine inventory on the eastern slopes of Cordón del Plata and Cordón del Portillo, central Andes, Argentina. In Evenson E B, Schlüchter C, Rabassa J (eds). Tills and related deposits; genesis/pctrology/application/stratigraphy. Proceedings of the INQUA symposia on the genesis and lithology of Quaternary deposits/USA 1981/Argentina 1982. Rotterdam, A A Balkema: $381-395$

Eyles N 1979 Facies of supraglacial sedimentation on Icelandic and Alpine temperate glaciers. Canadian Journal of Earth Sciences 16(7): 1341-1361

Haeberli W 1979 Holocene push-moraines in Alpine permafrost. Geografiska Annaler 61 A(1-2): 43-48

Haeberli W 1985 Creep of mountain permafrost: internal structure and flow of Alpine rock glaciers. Mitteilungen der Versuchsanstalt für Wasserbau, Hydrologie und Glaziologie an der Eidgenössischen Technischen Hochschule (Zürich) 77

Messerli B, Zurbuchen M 1968 Coulées de blocs au Weissmies et au glacier d'Aletsch et leur cartographie photogrammétrique. Die Alpen 44(3): 139-152

Müller F 1970 Perennial ice and snow masses; a guide for compilation and assemblage of data for a world inventory. Technical Papers in Hydrology. Series on Snow and Ice. Paris, International Association of Hydrological Sciences and UNESCO

Østrem G 1971 Rock glaciers and ice-cored moraines: a reply to D. Barsch. Geografiska Annaler 53A(3-4): $207-213$

Outcalt S I, Benedict J B 1965 Photo-interpretation of two types of rock glacier in the Colorado Front Range, U.S.A. Journal of Glaciology 5(42): 849-856

Potter N Jr 1972 Ice-cored rock glacier, Galena Creek, northern Absaroka Mountains, Wyoming. Geological Society of America. Bulletin 83(10): 3025-3057

Washburn A L 1979 Geocryology; a survey of periglacial processes and environments. London, Edward Arnold

Whalley W B 1979 The relationship of glacier ice and rock glacier at Grubengletscher, Kanton Wallis, Switzerland. Geografiska Annaler $61 \mathrm{~A}(1-2)$ : $49-61$

Whalley W B 1983 Rock glaciers - permafrost features or glacial relics? In Fourth International Conference on Permafrost, Fairbanks, Alaska, July $17-22,1983$. Proceedings. Washington, DC, National Academy Press: $1396-1401$

White S E 1976 Rock glaciers and block fields; review and new data. Quaternary Research 6(1): 77-97

White S E 1981 Alpine mass movement forms (noncatastrophic): classification, description, and significance. Arctic and Alpine Research 13(2): 127-137 